\title{
Spent Lead-Acid Battery Recycling via Reductive Sulfur-Fixing Smelting and Its Reaction Mechanism in the $\mathrm{PbSO}_{4}-\mathrm{Fe}_{3} \mathrm{O}_{4^{-}}$ $\mathrm{Na}_{2} \mathrm{CO}_{3}-\mathrm{C}$ System
}

\author{
YUN LI, ${ }^{1,2}$ SHENGHAI YANG,${ }^{1}$ PEKKA TASKINEN,${ }^{2}$ JING HE, ${ }^{1}$ \\ YONGMING CHEN, ${ }^{1,4}$ CHAOBO TANG, ${ }^{1,5}$ YUEJUN WANG, ${ }^{3,6}$ \\ and ARI JOKILAAKSO ${ }^{1,2,7}$ \\ 1.-School of Metallurgy and Environment, Central South University, Changsha 410083, China. \\ 2.-Department of Chemical and Metallurgical Engineering, Aalto University, 02150 Espoo, \\ Finland. 3.-Department of Ecology and Resources Engineering, Hetao College, Bayannur \\ 015000, China. 4.-e-mail: csuchenyongming@163.com. 5.-e-mail: chaobotang@163.com. \\ 6.—e-mail: thirtythree61@aliyun.com. 7.—e-mail: ari.jokilaakso@aalto.fi
}

An innovative and environmentally friendly lead-acid battery paste recycling method is proposed. The reductive sulfur-fixing recycling technique was used to simultaneously extract lead and immobilize sulfur. $\mathrm{SO}_{2}$ emissions and pollution were significantly eliminated. In this work, the detailed lead extraction and sulfur-fixing mechanisms in the $\mathrm{PbSO}_{4}-\mathrm{Fe}_{3} \mathrm{O}_{4}-\mathrm{Na}_{2} \mathrm{CO}_{3}-\mathrm{C}$ system were investigated thermodynamically and experimentally, and the phase transformation and microstructural evolution processes characterized. In addition, a series of bench-scale pilot experiments were carried out to confirm the feasibility of the technique. The results show that the lead extraction and sulfur-fixing reactions followed the shrinking unreacted-core model. The recycling products were separated into three distinct layers: slag, matte, and crude lead bullion. Primary recoveries of $96.2 \%$ for lead and $98.9 \%$ for sulfur were obtained. The purity of the crude lead bullion was 98.6 wt.\%. Sulfur was fixed in the solidified matte as $\mathrm{FeS}$ and $\mathrm{NaFeS}_{2}$.

\section{INTRODUCTION}

Spent lead-acid batteries (LABs) are widely scrapped from automobiles and electric bicycles in urban areas. The reported amounts of scrap LAB annually in China total more than 2.6 million metric tons. ${ }^{1,2}$ LABs are a solid waste and classified as hazardous materials in many countries. Their disposal has become a significant environmental concern. ${ }^{3}$ Recycling and reuse of LABs are attracting great attention from both the public and materials processing industry. At the same time, the depletion of high-quality lead ores resulting in rising extraction costs presents critical challenges for the lead extractive metallurgical industry. As a result, scrap LABs have become a significant secondary lead source worldwide. ${ }^{1}$ Secondary lead produced by recycling is gradually dominating the world's lead market. ${ }^{4}$ Typically, a spent LAB consists of four components: waste electrolyte (11-
$30 \%$ ), polymeric materials (22-30\%), lead alloy grids (24-30\%), and lead paste (30-40\%). Of these, lead paste is the most difficult part to deal with. ${ }^{5}$ However, it is a high-quality secondary lead-bearing material. Around $80-85 \%$ of the total secondary lead is recycled from lead paste. ${ }^{6}$

Currently, the worldwide LAB recycling technology can be divided into traditional routes such as pyrometallurgy and hydrometallurgy, and advanced approaches including electrowinning, ${ }^{7}$ biological techniques, ${ }^{8,9}$ and vacuum methods. ${ }^{5}$ Pyrometallurgy is presently the predominant route worldwide for recycling $\mathrm{LAB},{ }^{10}$ in which high-temperature treatment of spent LABs in a blast, electric, reverberatory, or rotary furnace without pre-desulfurization is employed. ${ }^{11,12}$ In the hydrometallurgical process, ${ }^{13,14}$ a pre-desulfurization step ${ }^{15}$ is necessary. $\mathrm{Na}_{2} \mathrm{CO}_{3}, \mathrm{NaOH}$, and $\mathrm{K}_{2} \mathrm{CO}_{3}$ solutions or citric acid and citrate salts are usually adopted as desulfurization reagents. However, the 
treatment of spent LABs involves a potential health and environmental risk. ${ }^{16,17}$ At the same time, existing LAB pyrometallurgical processes operated at high temperatures are usually associated with high atmospheric emissions, since dioxins, chloride compounds, and mercury can be generated in the process. Meanwhile, hydrometallurgical processes are accompanied by laborious procedures, generation of large amounts of problematic waste water, and high electricity consumption. ${ }^{18}$ As a result, the stringent environmental requirements are increasingly difficult to meet with current pyro- and hydrometallurgical recycling technologies. Therefore, the lead industry is keen to seek advanced technologies ${ }^{19}$ which are more economical, minimize environmental pollution, ${ }^{20}$ and reduce energy usage and production costs.

In this article, an innovative and environmentally friendly lead-acid battery paste recycling method is proposed. The reductive sulfur-fixing ${ }^{21-23}$ technique was used to simultaneously extract lead and immobilize sulfur. This novel technique is distinguished from conventional pyrometallurgy techniques such as oxidizing matte smelting and reductive smelting by the use of a reducing atmosphere in the processing combined with sulfur transformation and fixation as a sulfide matte. Iron-containing wastes are also employed as sulfur-fixing agents to immobilize sulfur as FeS. The smelting products obtained contain three products, namely crude metal bullion, matte, and slag. The novelty of this process is the treatment of various iron/lead-bearing wastes, $\mathrm{SO}_{2}$ free sulfur fixation, a much shorter flowsheet, absence of harmful byproducts, and wide adaptability for different secondary materials. ${ }^{12}$ This work investigated the detailed lead extraction and sulfurfixing mechanisms in the $\mathrm{PbSO}_{4}-\mathrm{Fe}_{3} \mathrm{O}_{4}-\mathrm{Na}_{2} \mathrm{CO}_{3}-\mathrm{C}$ system, thermodynamically and experimentally. The phase transformations and microstructural evolution processes were characterized, and the lead extraction and sulfur-fixing reaction mechanisms proposed. Furthermore, bench-scale experiments were carried out to confirm the feasibility and reliability of the new technique.

\section{EXPERIMENTAL PROCEDURES}

\section{Materials}

In the reaction mechanism investigation, $\mathrm{PbSO}_{4}$, $\mathrm{Na}_{2} \mathrm{CO}_{3}, \mathrm{Fe}_{3} \mathrm{O}_{4}$, and carbon powder with purity of $\geq 99 \%$ were employed to ensure high experimental accuracy. In the batch tests, lead paste separated from LAB scrap was used as raw material. Hematite and coke obtained from Jiuquan Iron \& Steel Co., Ltd., Gansu, China were applied as sulfur-fixing agent and reductant, respectively. Their chemical compositions were analyzed by inductively coupled plasma-atomic emission spectrometry (ICP-AES, PerkinElmer, Optima 3000, Norwalk, USA) and are shown in Supplementary Table S-I (Online Supplementary Material). The phase compositions of the lead paste and hematite were characterized by x-ray diffraction (XRD) analysis (D/max 2550PC, Rigaku Co., Ltd., Japan). The results are presented in Supplementary Fig. S-1, showing that the lead paste comprised $56.3 \% \mathrm{PbSO}_{4}, 18.9 \% \mathrm{PbO}_{2}, 13.7 \%$ $\mathrm{Pb}$, and $11.1 \% \mathrm{PbO}$. Lead sulfate (anglesite) is the main substance in the lead paste. Hematite mainly contains $\mathrm{Fe}_{2} \mathrm{O}_{3}$ and $(\mathrm{Mg}, \mathrm{Al})_{6}(\mathrm{Si}, \mathrm{Al})_{4} \mathrm{O}_{10}(\mathrm{OH})_{8}, \mathrm{SiO}_{2}$, and $\mathrm{Ca}(\mathrm{Al}, \mathrm{Si})_{2} \mathrm{O}_{4}$.

\section{Methods}

$\mathrm{PbSO}_{4}$ was selected as a model compound in the reaction mechanism investigation, since it is the major as well as the most difficult component to deal with in spent lead paste. At the same time, to reveal the reaction paths that may take place in each raw material component, the $\mathrm{PbSO}_{4}-\mathrm{Fe}_{3} \mathrm{O}_{4}-\mathrm{Na}_{2} \mathrm{CO}_{3}-\mathrm{C}$ system was divided into the $\mathrm{PbSO}_{4}-\mathrm{Na}_{2} \mathrm{CO}_{3}, \mathrm{PbSO}_{4^{-}}$ $\mathrm{Na}_{2} \mathrm{CO}_{3}-\mathrm{C}, \mathrm{PbSO}_{4}-\mathrm{Fe}_{3} \mathrm{O}_{4}$, and $\mathrm{PbSO}_{4}-\mathrm{Fe}_{3} \mathrm{O}_{4}-\mathrm{C}$ subsystems. The specimens were mixed carefully and pressed uniaxially under $15 \mathrm{MPa}$ into cylindrical samples of $10 \mathrm{~mm}$ diameter. Each specimen was placed in an alumina crucible and pushed slowly into the constant-temperature zone of a horizontal tube furnace (Supplementary Fig. S-2). The temperature was measured using a Pt-Rh thermocouple and controlled using a SHIMADEN SR25 intelligent temperature controller (accuracy $\pm 1^{\circ} \mathrm{C}$ ). Nitrogen with purity of $99 \%$ was applied as protective gas in the reaction mechanism investigations. The $\mathrm{N}_{2}$ gas flow during the reaction was fixed at $0.5 \mathrm{~L} / \mathrm{min}$. After the preset smelting time, the sample was removed rapidly from the furnace and quenched in liquid nitrogen.

In the bench-pilot confirmation experiments, $2000 \mathrm{~g}$ LAB paste was mixed thoroughly with a desired proportion of hematite, coke, $\mathrm{Na}_{2} \mathrm{CO}_{3}$, and other fluxes $\left(\mathrm{CaO}\right.$ and $\left.\mathrm{SiO}_{2}\right)$. The specimen was loaded into an alumina crucible and put into a chamber furnace. After the required smelting time, the sample was taken out and cooled down at room temperature. Next, the crucible was broken to carefully separate and weigh the end products obtained, i.e., crude lead, ferrous matte, and slag. Each product was prepared for ICP-AES analysis. The direct recovery rate of $\mathrm{Pb}(\eta)$ and the sulfurfixing rate $(\gamma)$ were calculated based on Eqs. 1 and 2, respectively:

$$
\begin{gathered}
H=\frac{\text { Mass of } \mathrm{Pb} \text { in the crude lead }}{\text { Mass of Pb in the initial feed materials }} \times 100 \% \\
\gamma=\frac{\text { Mass of sulfur in the condensed solid smelting products }}{\text { Mass of sulfur in the initial feed materials }} \times 100 \%
\end{gathered}
$$

The phases and microstructure of the samples were characterized by XRD using $\mathrm{Cu} \mathrm{K}_{\alpha}$ radiation and scanning electron microscope with energy- 
dispersive spectroscopy (SEM-EDS, Carl Zeiss LEO 1450, Germany; EDS, INCA Wave 8570, Oxford Instruments, UK). XRD data were collected in the $2 \theta$ range from $10^{\circ}$ to $80^{\circ}$ in steps of $1^{\circ}$. The recorded patterns were evaluated using the PDF-2 powder XRD database. ${ }^{24}$ Samples for SEM-EDS analysis were mounted in epoxy resin and polished using conventional metallographic grinding and polishing techniques.

\section{THERMODYNAMIC CALCULATIONS}

Figure 1 illustrates the equilibrium compositions of the $\mathrm{PbSO}_{4}-\mathrm{Fe}_{3} \mathrm{O}_{4}-\mathrm{Na}_{2} \mathrm{CO}_{3}-\mathrm{C}$ reaction system for different carbon additions as simulated using HSC Chemistry software, version 9.2.6, and its database ${ }^{25}$ the phase diagrams of the $\mathrm{Al}_{2} \mathrm{O}_{3}-\mathrm{SiO}_{2}-\mathrm{CaO}$ 10 wt. $\% \mathrm{Na}_{2} \mathrm{O}$ and $\mathrm{Fe}-\mathrm{Fe}_{3} \mathrm{O}_{4}-\mathrm{FeS}$ systems were calculated using MTDATA version $6.0^{26}$ and MTOX database 8.2. ${ }^{27}$ Figure 1a suggests that, without carbon addition, $\mathrm{PbSO}_{4}$ prefers to react with $\mathrm{Na}_{2} \mathrm{CO}_{3}$ to produce $\mathrm{Na}_{2} \mathrm{SO}_{4}$ and $\mathrm{PbO}$, even below $200^{\circ} \mathrm{C}$. As the temperature is increased above $500^{\circ} \mathrm{C}$, some $\mathrm{PbO}$ decomposes to metallic lead. In a weakly reductive atmosphere, as shown in Fig. $1 b, \mathrm{PbSO}_{4}$ is reduced to $\mathrm{PbS}$. At the same time, as the temperature increases, $\mathrm{PbS}$ prefers to react further with $\mathrm{Fe}_{3} \mathrm{O}_{4}$, instead of $\mathrm{Na}_{2} \mathrm{CO}_{3}$, generating metallic $\mathrm{Pb}$ and $\mathrm{FeS}$. However, when the temperature reaches around $630^{\circ} \mathrm{C}, \mathrm{Na}_{2} \mathrm{CO}_{3}$ gradually reacts with $\mathrm{FeS}$ as well as $\mathrm{PbS}$. Thus, the amounts of $\mathrm{Pb}, \mathrm{Na}_{2} \mathrm{~S}$, and $\mathrm{Fe}_{3} \mathrm{O}_{4}$ products increase, while those of $\mathrm{PbS}, \mathrm{Na}_{2} \mathrm{CO}_{3}$, and $\mathrm{FeS}$ decrease. However, some $\mathrm{PbS}$ remains due to insufficient addition of carbon.
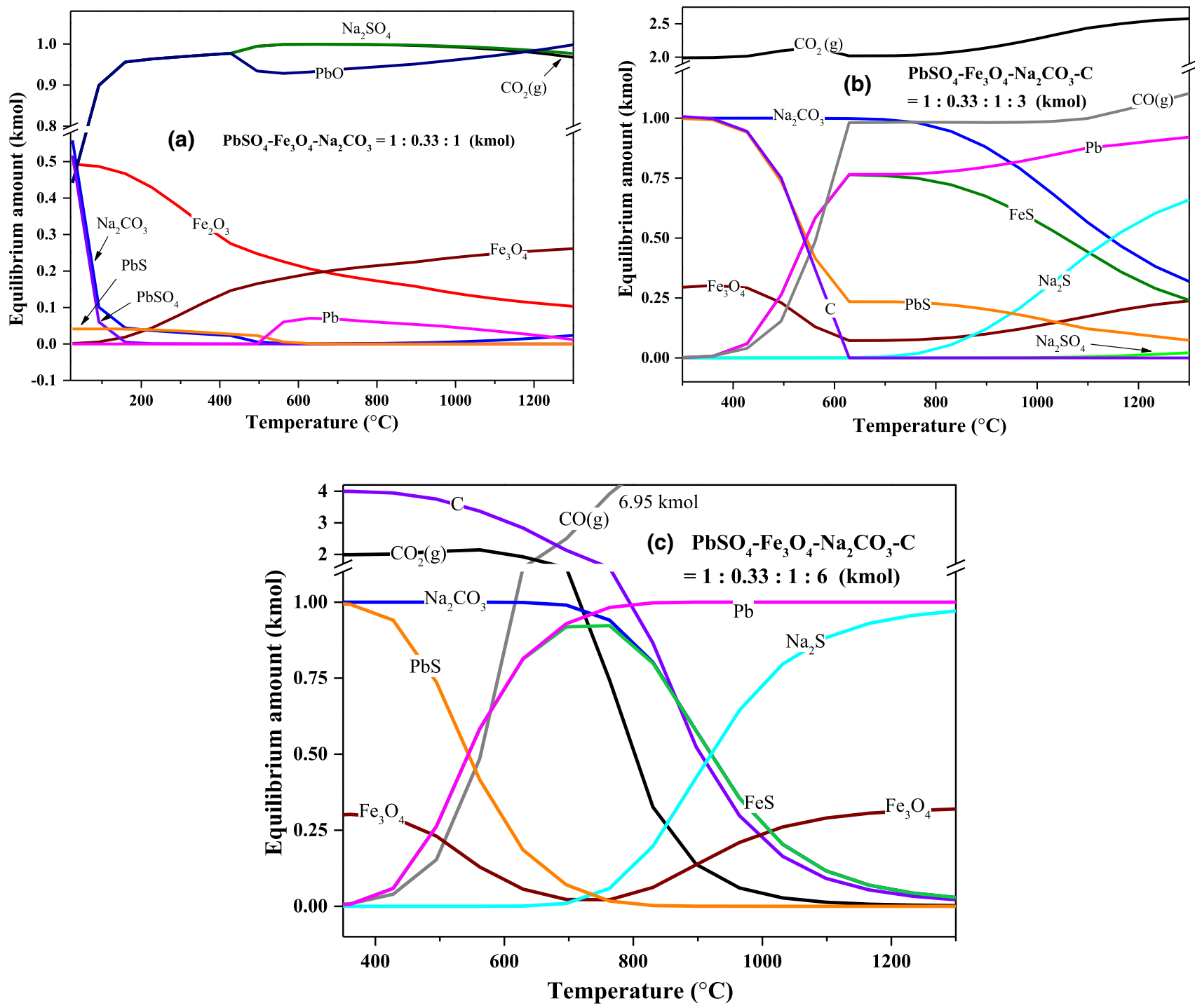

Fig. 1. Equilibrium compositions (a)-(c) of the $\mathrm{PbSO}_{4}-\mathrm{Fe}_{3} \mathrm{O}_{4}-\mathrm{Na}_{2} \mathrm{CO}_{3}-\mathrm{C}$ reaction system calculated for different carbon additions; data taken from $\mathrm{HSC}$ 9.2.6 and its database, ${ }^{25}$ and liquidus contour diagrams of (d) the $\mathrm{Al}_{2} \mathrm{O}_{3}-\mathrm{SiO}_{2}-\mathrm{CaO}-10$ wt. $\% \mathrm{Na}_{2} \mathrm{O}$ system and (e) the $\mathrm{Fe}-\mathrm{Fe} \mathrm{O}_{3} \mathrm{O}_{4}-\mathrm{FeS}$ system calculated using MTDATA version 6.0 and MTOX database 8.2. ${ }^{27}$ 
Spent Lead-Acid Battery Recycling via Reductive Sulfur-Fixing Smelting and Its Reaction
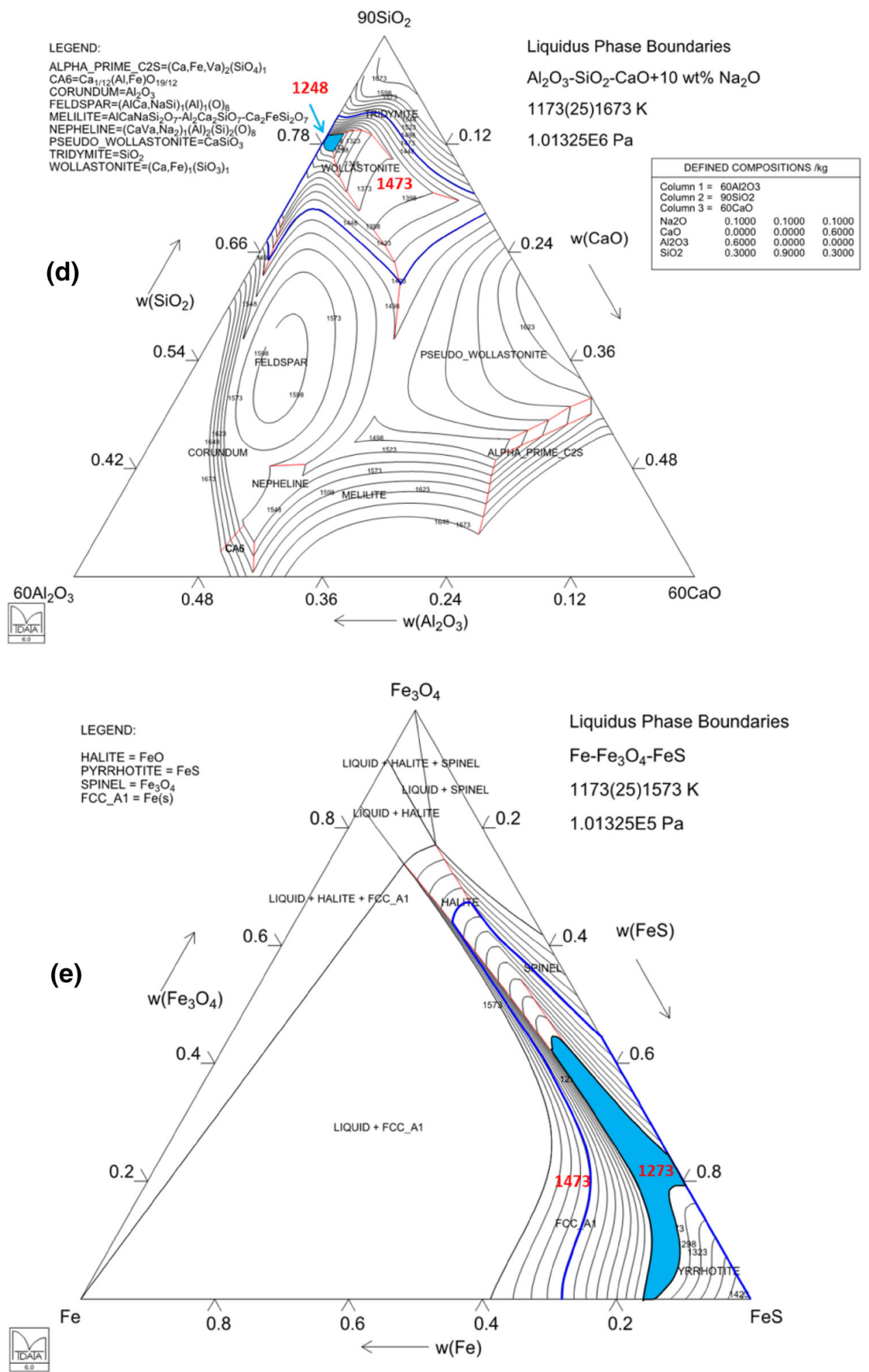

Fig. 1. continued.

Figure 1c indicates that, at equilibrium conditions, all the lead can be extracted from $\mathrm{PbSO}_{4}$ and $\mathrm{PbS}$ before $800^{\circ} \mathrm{C}$ when the carbon addition is sufficient. However, when the temperature is increased from $700^{\circ} \mathrm{C}$ to $800^{\circ} \mathrm{C}$, the equilibrium amount of FeS remains steady while the amounts of metallic $\mathrm{Pb}$ and $\mathrm{Na}_{2} \mathrm{~S}$ increase and, at the same time, those of $\mathrm{Na}_{2} \mathrm{CO}_{3}$ as well as $\mathrm{PbS}$ decrease. This indicates that $\mathrm{Na}_{2} \mathrm{CO}_{3}$ is partly involved in the lead 

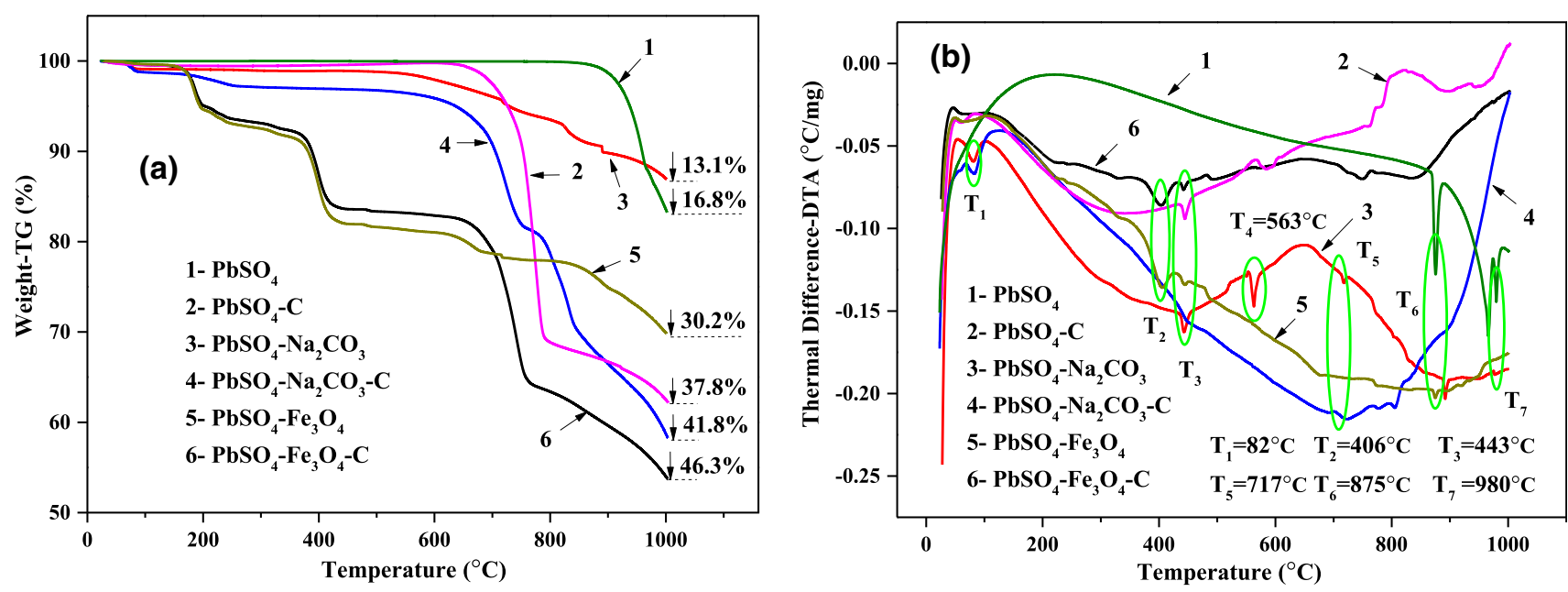

Fig. 2. Thermogravimetric behavior in different $\mathrm{PbSO}_{4}-\mathrm{Fe}_{3} \mathrm{O}_{4}-\mathrm{Na}_{2} \mathrm{CO}_{3}-\mathrm{C}$ subsystems (mole ratio 3:1:3:18): (a) TG curves, (b) DTA curves.

extraction reactions from $\mathrm{PbS}$. When the temperature exceeds $800^{\circ} \mathrm{C}$, some $\mathrm{FeS}$ will also react with $\mathrm{Na}_{2} \mathrm{CO}_{3}$ to generate $\mathrm{Na}_{2} \mathrm{~S}$ and $\mathrm{Fe}_{3} \mathrm{O}_{4}$.

The above thermodynamic equilibrium composition calculations reveal that, in the absence of a reducing agent and below $200^{\circ} \mathrm{C}, \mathrm{PbSO}_{4}$ prefers to react with $\mathrm{Na}_{2} \mathrm{CO}_{3}$ rather than $\mathrm{Fe}_{3} \mathrm{O}_{4}$ to generate $\mathrm{PbO}$ and $\mathrm{Na}_{2} \mathrm{SO}_{4}$. Once the temperature is increased and the atmosphere is sufficiently reducing, $\mathrm{PbSO}_{4}$ will be reduced to $\mathrm{PbS}$. At that point, $\mathrm{PbS}$ will prefer to react with $\mathrm{Fe}_{3} \mathrm{O}_{4}$ rather than $\mathrm{Na}_{2} \mathrm{CO}_{3}$ to produce $\mathrm{FeS}$ and $\mathrm{PbO}$. When the temperature exceeds $800^{\circ} \mathrm{C}$, the excess $\mathrm{Na}_{2} \mathrm{CO}_{3}$ will continue to react with $\mathrm{FeS}$. Thus, the sulfur transfers from the initial $\mathrm{PbSO}_{4}$ to $\mathrm{PbS}$ and then $\mathrm{FeS}$, and finally to $\mathrm{Na}_{2} \mathrm{~S}$. As a result, the presence of $\mathrm{Na}_{2} \mathrm{CO}_{3}$, and a reductant as well as sulfur-fixing agent $\mathrm{Fe}_{3} \mathrm{O}_{4}$, can ensure efficient sulfur fixation and lead extraction at both low and high temperature. No gaseous $\mathrm{SO}_{2}$ or $\mathrm{SO}_{3}$ is generated throughout the whole reaction process. All lead can thus be extracted from $\mathrm{PbSO}_{4}$ and $\mathrm{PbS}$.

The phase diagrams of the $\mathrm{Al}_{2} \mathrm{O}_{3}-\mathrm{SiO}_{2}-\mathrm{CaO}$ 10 wt. $\% \mathrm{Na}_{2} \mathrm{O}$ system shown in Fig. $1 \mathrm{~d}$ indicate that the first liquid slag appeared below around $975^{\circ} \mathrm{C}$ $(1248 \mathrm{~K})$, surrounded by liquid wollastonite $\left[(\mathrm{Ca}, \mathrm{Fe}) \mathrm{SiO}_{3}\right]$, tridymite $\left(\mathrm{SiO}_{2}\right)$, and feldspar [(AlCa, $\mathrm{NaSi}) \mathrm{AlO}_{8}$ ]. At that point, $\mathrm{PbS}, \mathrm{FeS}$, metallic $\mathrm{Pb}, \mathrm{Na}_{2} \mathrm{SO}_{4}$, and $\mathrm{Na}_{2} \mathrm{~S}$ were generated in the smelting system, as shown in Fig. 1a-c. They stayed in liquid form, together with the remaining $\mathrm{Fe}_{3} \mathrm{O}_{4}$ and liquid $\mathrm{Na}_{2} \mathrm{CO}_{3}$. As the temperature was increased further, more liquid was formed from $(\mathrm{Ca}, \mathrm{Fe}) \mathrm{SiO}_{3}$ and other solid smelting materials. When the temperature reached $1200^{\circ} \mathrm{C}(1473 \mathrm{~K})$, more tridymite $\left(\mathrm{SiO}_{2}\right)$ and feldspar [( $\mathrm{AlCa}, \mathrm{Na}-$ $\mathrm{Si}) \mathrm{AlO}_{8}$ ] also dissolved in the melt, and the liquid slag region expanded.

Figure 1e further reveals that pyrrhotite $\mathrm{FeS}$ melts may come into contact with spinel $\mathrm{Fe}_{3} \mathrm{O}_{4}$, halite $\mathrm{FeO}$, or/and FCC-A1 Fe before $1000^{\circ} \mathrm{C}$
(1273 K). A eutectic iron sulfide-oxide liquid appeared and gradually expanded along with the temperature. At $1200^{\circ} \mathrm{C}(1473 \mathrm{~K}), \mathrm{FeS}$ was in liquid form. This promoted the generation of $\mathrm{FeS}$ and its settling from the smelting system as a separate sulfide melt layer.

\section{RESULTS AND DISCUSSION}

\section{Thermogravimetric Behavior of $\mathrm{PbSO}_{4}-\mathrm{Fe}_{3} \mathrm{O}_{4}$ - $\mathrm{Na}_{2} \mathrm{CO}_{3}-\mathrm{C}$ Mixtures}

The thermogravimetric behavior of the reactants and their mixtures was characterized using a thermogravimetric analyzer (TG-DTA, STA 494 F3; Netzsch, Germany) at heating rate of $10^{\circ} \mathrm{C} / \mathrm{min}$ in $\mathrm{N}_{2}$ flow of $100 \mathrm{~mL} / \mathrm{min}$, from 25 to $1000^{\circ} \mathrm{C}$. The results are shown in Fig. 2.

It can be observed from Fig. 2a that the weight loss in the $\mathrm{PbSO}_{4}-\mathrm{C}, \mathrm{PbSO}_{4}-\mathrm{Na}_{2} \mathrm{CO}_{3}-\mathrm{C}$, and $\mathrm{PbSO}_{4}-$ $\mathrm{Fe}_{3} \mathrm{O}_{4}$-C subsystems was greater than that in the $\mathrm{PbSO}_{4}, \mathrm{PbSO}_{4}-\mathrm{Fe}_{3} \mathrm{O}_{4}$, and $\mathrm{PbSO}_{4}-\mathrm{Na}_{2} \mathrm{CO}_{3}$ subsystems. This implies that the presence of carbon promoted the conversion of $\mathrm{PbSO}_{4}$. Figure $2 \mathrm{~b}$ further illustrates that $T_{1}$ (around $82^{\circ} \mathrm{C}$ ) is associated with loss of crystallographic water from $\mathrm{Na}_{2} \mathrm{CO}_{3} . T_{2}$ $\left(406^{\circ} \mathrm{C}\right)$ is ascribed to the transformation of $\mathrm{Fe}_{3} \mathrm{O}_{4}$ into crystal form. $T_{3}\left(443^{\circ} \mathrm{C}\right)$ corresponds to preliminary decomposition of $\mathrm{PbSO}_{4} \cdot T_{4}\left(563^{\circ} \mathrm{C}\right)$ and $T_{5}$ $\left(717^{\circ} \mathrm{C}\right)$ are associated with the conversion reactions between $\mathrm{PbSO}_{4}$ and $\mathrm{Na}_{2} \mathrm{CO}_{3}$. The pronounced endothermic peaks detected at $T_{6}$ (around $875^{\circ} \mathrm{C}$ ) can be attributed to further decomposition of $\mathrm{PbSO}_{4}$. The last obvious endothermic peaks recorded at $T_{7}$ (around $980^{\circ} \mathrm{C}$ ) are assumed to be linked with the generation of metallic lead.

\section{Experimental Reaction Mechanisms in the $\mathrm{PbSO}_{4}-\mathrm{Na}_{2} \mathrm{CO}_{3}-\mathrm{C}$ Mixture}

The experimental phase transformation paths in the different reaction systems and at different temperatures and reaction times were characterized 

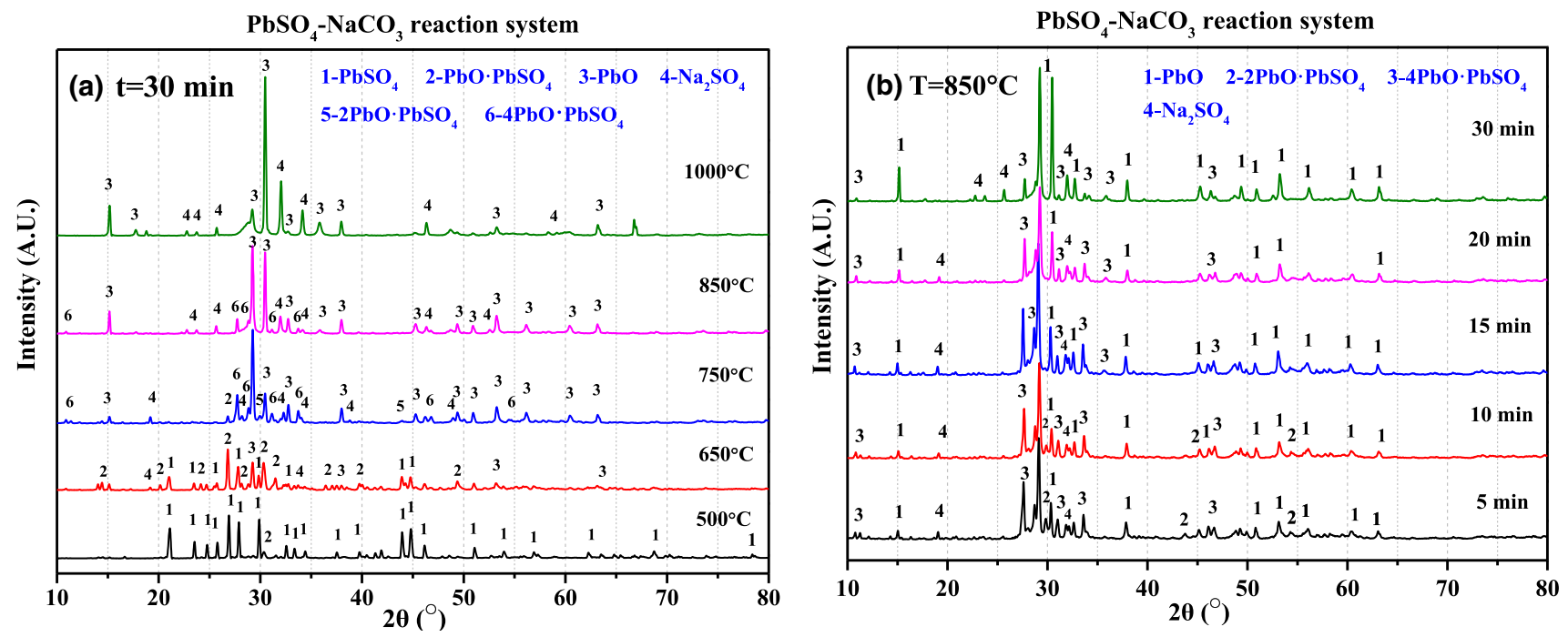

$\mathrm{PbSO}_{4}-\mathrm{NaCO}_{3}-\mathrm{C}$ reaction system
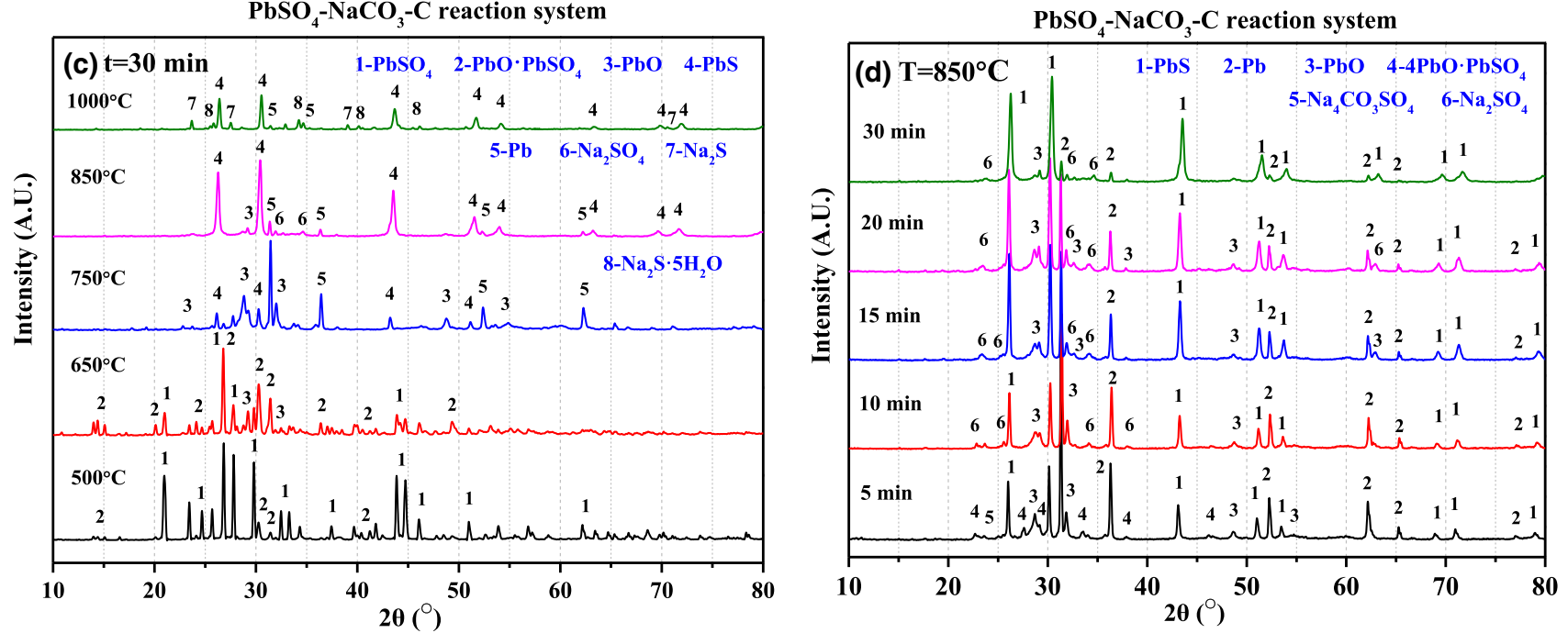

Fig. 3. Phase transformation paths in (a) the $\mathrm{PbSO}_{4}-\mathrm{Na}_{2} \mathrm{CO}_{3}$ (mole ratio 1:1) reaction system at different smelting temperature after 30 min reaction time; (b) the $\mathrm{PbSO}_{4}-\mathrm{Na}_{2} \mathrm{CO}_{3}$ (mole ratio 1:1) reaction system at $850^{\circ} \mathrm{C}$ for different reaction times; (c) the $\mathrm{PbSO}_{4}-\mathrm{Na}_{2} \mathrm{CO}_{3}-\mathrm{C}(\mathrm{mole}$ ratio $1: 1: 6$ ) reaction system at different smelting temperatures after 30 min reaction time; (d) the $\mathrm{PbSO}_{4}-\mathrm{Na}_{2} \mathrm{CO}_{3}-\mathrm{C}$ (mole ratio $1: 1: 6$ ) reaction system at $850^{\circ} \mathrm{C}$ for different reaction times.

by XRD and SEM-EDS analyses. The results for the $\mathrm{PbSO}_{4}-\mathrm{Na}_{2} \mathrm{CO}_{3}-\mathrm{C}$ system are shown in Fig. 3. It was observed that the reactions between $\mathrm{PbSO}_{4}$ and $\mathrm{Na}_{2} \mathrm{CO}_{3}$ took place below $650^{\circ} \mathrm{C}$. $\mathrm{PbO}$ and $\mathrm{Na}_{2} \mathrm{SO}_{4}$ were detected at $650^{\circ} \mathrm{C}$ within a 30 -min duration. At the same time, when the temperature was increased, more intermediate products were detected, e.g., $\mathrm{PbO} \cdot \mathrm{PbSO}_{4}, \quad 2 \mathrm{PbO} \cdot \mathrm{PbSO}_{4}$, and $4 \mathrm{PbO} \cdot \mathrm{PbSO}_{4}$. This indicates that the reactions between $\mathrm{PbSO}_{4}$ and $\mathrm{Na}_{2} \mathrm{CO}_{3}$ are a multistage process and follow the shrinking unreacted-core model. The unreacted $\mathrm{PbSO}_{4}$ core is surrounded by liquid $\mathrm{Na}_{2} \mathrm{CO}_{3}$. The products $x \mathrm{PbO} \cdot \mathrm{PbSO}_{4}(x=1,2$, or 4) form a boundary layer. When the temperature exceeded $1000^{\circ} \mathrm{C}$, the reactions were completed and the final products were stable in $\mathrm{PbO}$ and $\mathrm{Na}_{2} \mathrm{SO}_{4}$. No metallic $\mathrm{Pb}$ was detected due to the absence of reductant. These results agree well with the thermodynamic calculations presented in Fig. 1. Figure 3b further reveals that the exchange reactions between $\mathrm{PbSO}_{4}$ and $\mathrm{Na}_{2} \mathrm{CO}_{3}$ favorably occur at $850^{\circ} \mathrm{C}$ quickly, within as little as $5 \mathrm{~min}$. Thus, $\mathrm{SO}_{3}$ in $\mathrm{PbSO}_{4}$ was transformed and fixed to $\mathrm{Na}_{2} \mathrm{SO}_{4}$, instead of being emitted to the furnace atmosphere. The presence of $\mathrm{Na}_{2} \mathrm{CO}_{3}$ inhibited self-decomposition of $\mathrm{PbSO}_{4}$.

Once a reductant was present, as shown in Fig. 3c and $\mathrm{d}, \mathrm{PbSO}_{4}$ was reduced to $\mathrm{PbS}$ when the temperature was higher than $750^{\circ} \mathrm{C}$. Metallic $\mathrm{Pb}$ was also detected. This implies that $\mathrm{PbO}$ had been reduced by carbon. Furthermore, as the temperature was increased to $1000^{\circ} \mathrm{C}$, the stable sodiumbearing product after $30 \mathrm{~min}$ reaction time was $\mathrm{Na}_{2} \mathrm{~S}$, rather than $\mathrm{Na}_{2} \mathrm{SO}_{4}$. This indicates that $\mathrm{Na}_{2} \mathrm{SO}_{4}$ had been reduced to $\mathrm{Na}_{2} \mathrm{~S}$. The final products were $\mathrm{PbS}, \mathrm{Pb}$, and $\mathrm{Na}_{2} \mathrm{~S}$. 
The reaction paths in the $\mathrm{PbSO}_{4}-\mathrm{Na}_{2} \mathrm{CO}_{3} \mathrm{C}$ system at $850^{\circ} \mathrm{C}$ after different reaction times, which are illustrated in Fig. 3d, further reveal that the $\mathrm{PbSO}_{4}$ and $\mathrm{PbO}$ reduction reactions can occur rapidly. $\mathrm{PbS}$ and metallic $\mathrm{Pb}$ appeared within 5 min reaction time. The presence of carbon thus changes the reaction paths in the $\mathrm{PbSO}_{4}-\mathrm{Na}_{2} \mathrm{CO}_{3}$ system. Only very weak diffraction peaks of $\mathrm{PbO}$, $\mathrm{Na}_{4} \mathrm{CO}_{3} \mathrm{SO}_{4}$, and $\mathrm{Na}_{2} \mathrm{SO}_{4}$ were detected in the reaction products. The reduction of $\mathrm{PbSO}_{4}$ to $\mathrm{PbS}$ dominated the reaction path at $850^{\circ} \mathrm{C}$. The sulfur in $\mathrm{PbSO}_{4}$ would be converted mainly to $\mathrm{PbS}$ rather than $\mathrm{Na}_{2} \mathrm{SO}_{4}$.

\section{Experimental Reaction Mechanisms in the $\mathrm{PbSO}_{4}-\mathrm{Fe}_{3} \mathrm{O}_{4}$-C Mixtures}

Figure 4 presents the phase evolutions in the $\mathrm{PbSO}_{4}-\mathrm{Fe}_{3} \mathrm{O}_{4}-\mathrm{C}$ system. It can be observed in
Fig. $4 \mathrm{a}$ and $\mathrm{b}$ that no reactions took place between $\mathrm{PbSO}_{4}$ and $\mathrm{Fe}_{3} \mathrm{O}_{4}$ in the absence of reductant, as only a decomposition product, viz. $\mathrm{PbO} \cdot \mathrm{PbSO}_{4}$ from $\mathrm{PbSO}_{4}$, was detected. With the addition of a reductant, as illustrated in Fig. $4 \mathrm{c}$, below $650^{\circ} \mathrm{C}, \mathrm{PbSO}_{4}$ was still not involved in any reaction with iron oxide during the first $30 \mathrm{~min}$. However, at $750^{\circ} \mathrm{C}, \mathrm{PbS}$ was detected, and $\mathrm{PbSO}_{4}$ also converted to $\mathrm{PbO} \cdot \mathrm{PbSO}_{4}$ and further to $2 \mathrm{PbO} \cdot \mathrm{PbSO}_{4}$, and metallic $\mathrm{Pb}$ emerged. This implies that, without $\mathrm{Na}_{2} \mathrm{CO}_{3}, \mathrm{PbSO}_{4}$ self-decomposition intensified. As the temperature increased to $850^{\circ} \mathrm{C}$, the product after $30 \mathrm{~min}$ reaction time consisted of $\mathrm{PbS}, \mathrm{Pb}$, and $\mathrm{Fe}_{3} \mathrm{O}_{4}$. Figure $4 \mathrm{~d}$ further illustrates that the $\mathrm{PbSO}_{4}$ reduction reactions to $\mathrm{PbS}$ could take place instantaneously. $\mathrm{PbSO}_{4}$ disappeared before it was involved in any reaction with $\mathrm{Fe}_{3} \mathrm{O}_{4}$. FeS did not emerge until $1000^{\circ} \mathrm{C}$ after $30 \mathrm{~min}$ reaction time, and was
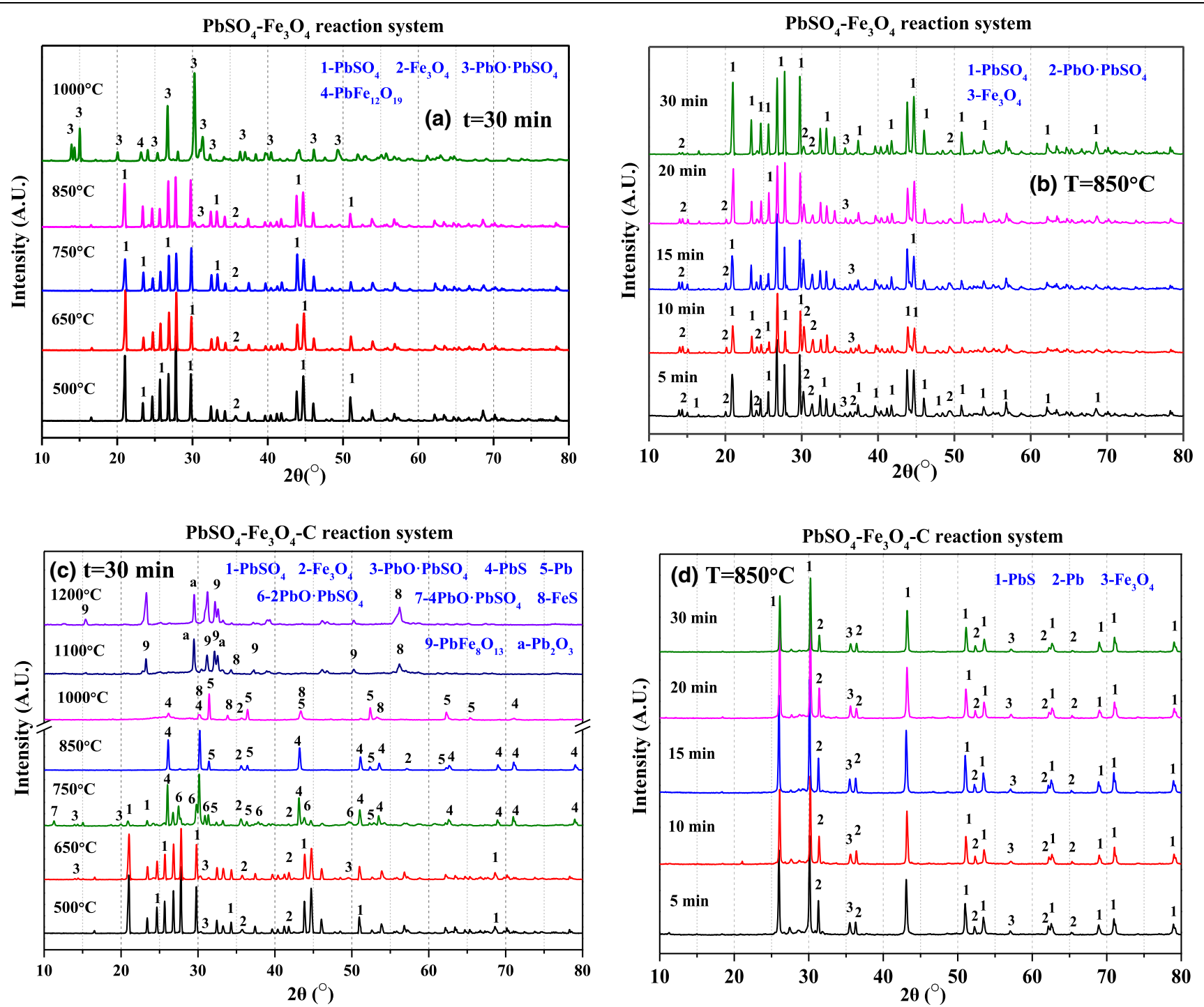

Fig. 4. Phase transformation paths in (a) the $\mathrm{PbSO}_{4}-\mathrm{Fe}_{3} \mathrm{O}_{4}$ (mole ratio $3: 1$ ) reaction system at different smelting temperatures after 30 min reaction time; (b) the $\mathrm{PbSO}_{4}-\mathrm{Fe}_{3} \mathrm{O}_{4}$ (mole ratio 3:1) reaction system at $850^{\circ} \mathrm{C}$ for different reaction times; (c) the $\mathrm{PbSO}_{4}-\mathrm{Fe}_{3} \mathrm{O}_{4}$ - $\mathrm{C}$ (mole ratio $3: 1: 18$ ) reaction system at different smelting temperatures after 30 min reaction time; (d) the $\mathrm{PbSO}_{4}-\mathrm{Fe}_{3} \mathrm{O}_{4}-\mathrm{C}$ (mole ratio $3: 1: 18$ ) reaction system at $850^{\circ} \mathrm{C}$ for different reaction times. 


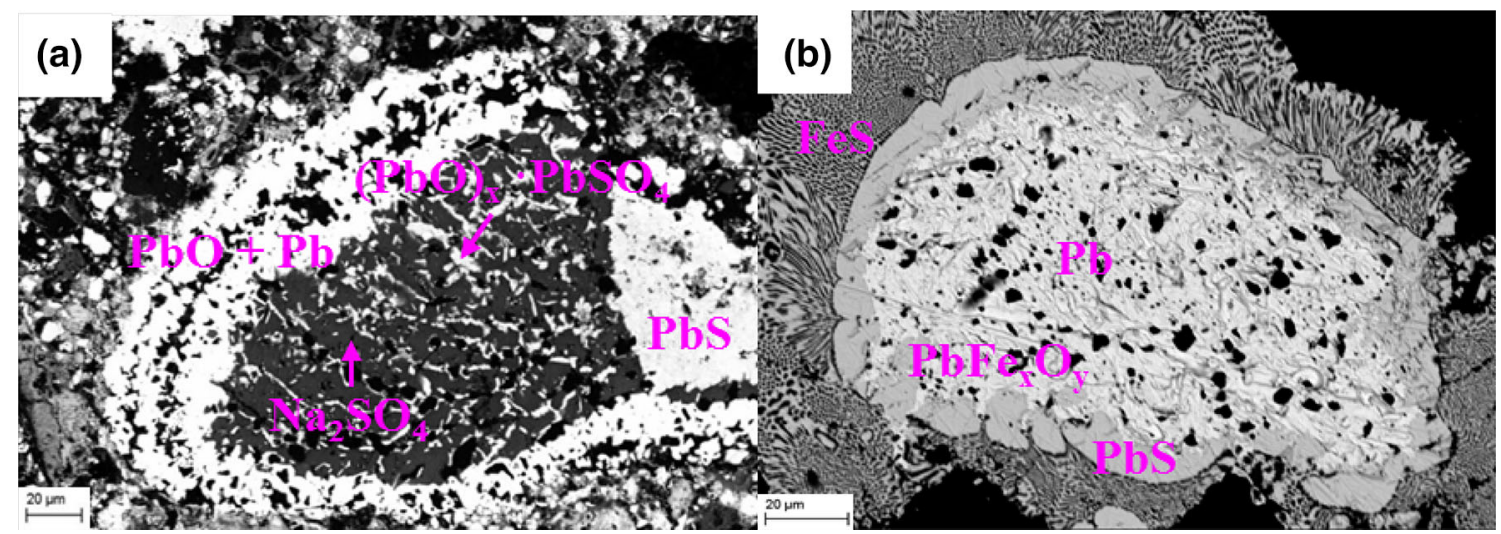

Fig. 5. SEM micrographs of products generated in (a) the $\mathrm{PbSO}_{4}-\mathrm{Na}_{2} \mathrm{CO}_{3}-\mathrm{C}$ system at $750^{\circ} \mathrm{C}$ after 30 min reaction and in (b) the $\mathrm{PbSO}_{4}-\mathrm{Fe}_{3} \mathrm{O}_{4}-$ $\mathrm{C}$ system at $850^{\circ} \mathrm{C}$ after 5 min reaction.

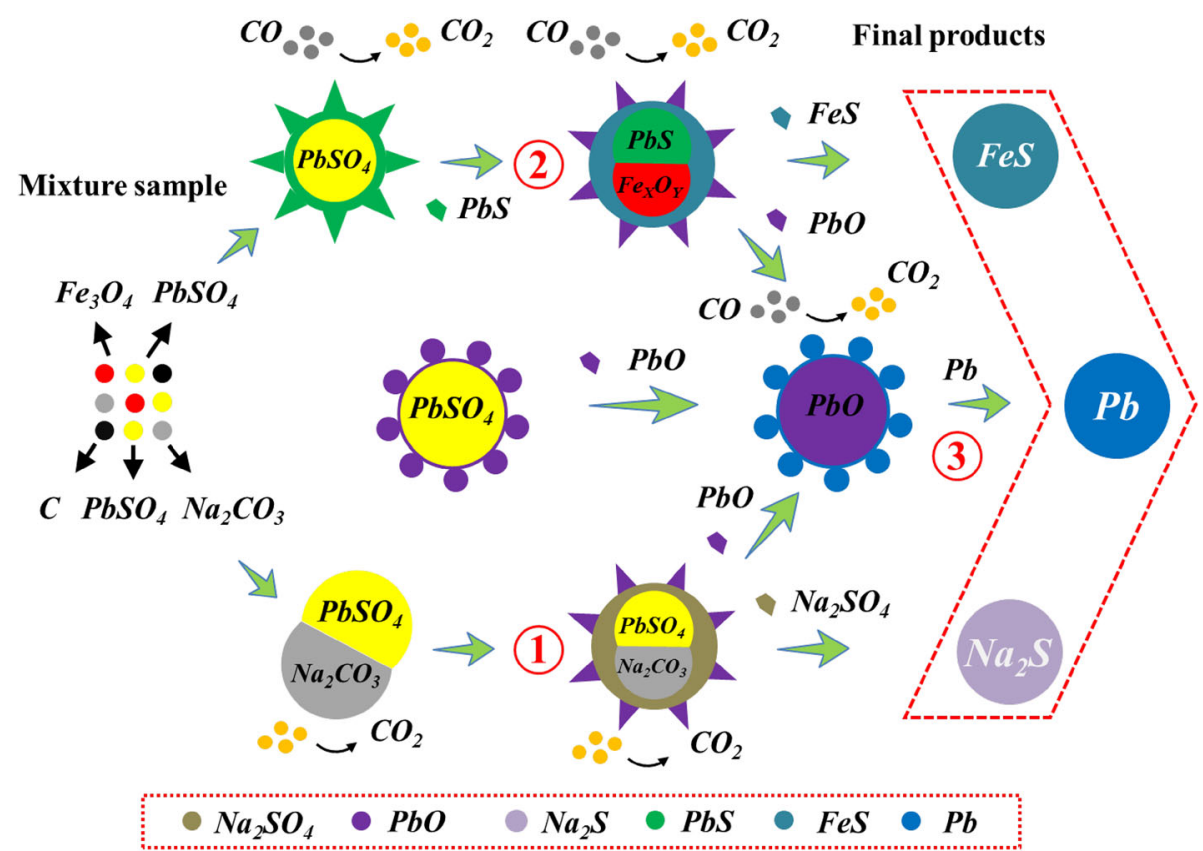

Fig. 6. Phase transformation and microstructural evolution mechanisms during reductive sulfur-fixing recycling process of scrap lead battery paste.

generated by the exchange reactions between $\mathrm{PbS}$ and $\mathrm{Fe}_{3} \mathrm{O}_{4} . \mathrm{PbSO}_{4}$ did not directly react with the sulfur-fixing agent, iron oxide. The sulfur-fixation reactions occurred with the help of exchange reactions between $\mathrm{PbSO}_{4}$ and $\mathrm{Na}_{2} \mathrm{CO}_{3}$, as well as $\mathrm{PbS}$ and $\mathrm{Fe}_{3} \mathrm{O}_{4}$. The reaction mechanism proposed is consistent with the thermodynamic results above.

\section{Microstructural Evolution Mechanisms}

Selected samples, produced from simulated smelting systems at different temperatures and reaction times, were further characterized by SEM-EDS analysis. The results are presented in Fig. 5. Figure 5a shows the SEM-EDS results for the $\mathrm{PbSO}_{4}$ $\mathrm{Na}_{2} \mathrm{CO}_{3}-\mathrm{C}$ system at $750^{\circ} \mathrm{C}$ for 30 min reactions. It was observed that $(\mathrm{PbO})_{x} \cdot \mathrm{PbSO}_{4}(x=1,2$, or 4$)$ was close to $\mathrm{Na}_{2} \mathrm{SO}_{4}$ particles and a part of $\mathrm{PbSO}_{4}$ had reduced to $\mathrm{PbS}$. Moreover, $\mathrm{PbSO}_{4}$ and $\mathrm{Na}_{2} \mathrm{SO}_{4}$ were surrounded by $\mathrm{PbO}$ and metallic $\mathrm{Pb}$. This confirms that the reactions between $\mathrm{PbSO}_{4}$ and $\mathrm{Na}_{2} \mathrm{CO}_{3}$ follow the shrinking unreacted-core model. $\mathrm{PbSO}_{4}$ first reacts with $\mathrm{Na}_{2} \mathrm{CO}_{3}$ to generate $\mathrm{Na}_{2} \mathrm{SO}_{4}$ and $\mathrm{PbO} . \mathrm{Na}_{2} \mathrm{CO}_{3}$ surrounds and gradually "erodes" the $\mathrm{PbSO}_{4}$ unreacted core, then the $\mathrm{PbSO}_{4}$ core is disintegrated by molten $\mathrm{Na}_{2} \mathrm{SO}_{4}$. At the same time, the reaction product $\mathrm{PbO}$ gradually diffuses out from the unreacted $\mathrm{PbSO}_{4}$ core.

Figure $5 \mathrm{~b}$ illustrates the SEM-EDS results for the $\mathrm{PbSO}_{4}-\mathrm{Fe}_{3} \mathrm{O}_{4}-\mathrm{C}$ system at $850^{\circ} \mathrm{C}$ after $5 \mathrm{~min}$ reaction time. It reveals that $\mathrm{PbS}$ was surrounded by $\mathrm{FeS}$. Metallic $\mathrm{Pb}$ was located in the center of the $\mathrm{PbS}$ particle. $\mathrm{A} \mathrm{PbFe}_{x} \mathrm{O}_{y}$ boundary layer was detected between the metallic $\mathrm{Pb}$ and $\mathrm{PbS}$ layers. This demonstrates that the reactions between $\mathrm{PbS}$ and $\mathrm{Fe}_{x} \mathrm{O}_{y}$ also follow the shrinking unreacted-core model. A possible phase transformation and 

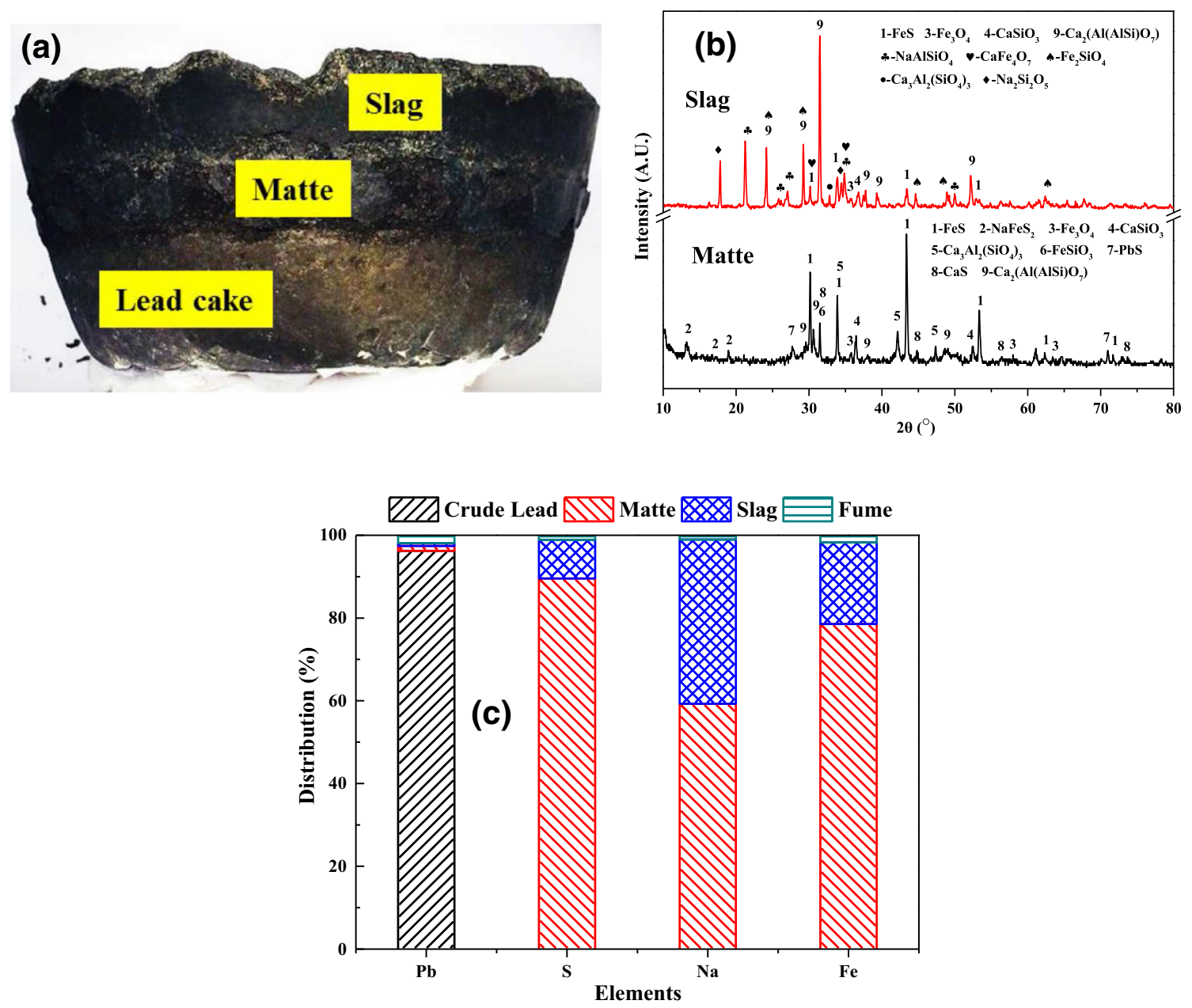

Fig. 7. (a) Macrograph of smelting products in bench-scale pilot experiments; (b) XRD patterns of matte and slag; (c) element distribution behavior ( $W_{\text {lead paste }}: W_{\text {hematite }}: W_{\mathrm{Na}_{2} \mathrm{CO}_{3}}: W_{\text {coke }}=1800 \mathrm{~g}: 360 \mathrm{~g}: 72 \mathrm{~g}: 216 \mathrm{~g}$. $\mathrm{FeO} / \mathrm{SiO}_{2}=1.3, \mathrm{CaO} / \mathrm{SiO}_{2}=0.4,1200^{\circ} \mathrm{C}, 1.5 \mathrm{~h}$ ).

microstructural evolution mechanism for the entire $\mathrm{PbSO}_{4}-\mathrm{Na}_{2} \mathrm{CO}_{3}-\mathrm{Fe}_{3} \mathrm{O}_{4}$-C reaction system is summarized and presented graphically in Fig. 6.

\section{Confirmation Experiments and Characteriza- tion of Products}

Two bench-scale pilot confirmation experiments with $1800 \mathrm{~g}$ lead paste were carried out to determine the reliability of this novel process under the following conditions: $W_{\text {lead paste }}: W_{\text {hematite }}: W_{\mathrm{Na}_{2} \mathrm{CO}_{3}}$ : $W_{\text {coke }}=100 \mathrm{~g}: 20 \mathrm{~g}: 4 \mathrm{~g}: 12 \mathrm{~g} . \quad \mathrm{FeO} / \mathrm{SiO}_{2}=1.3, \mathrm{CaO} /$ $\mathrm{SiO}_{2}=0.4$, smelting temperature of $1200^{\circ} \mathrm{C}$, and smelting time of $1.5 \mathrm{~h}$. A physical macrograph and corresponding XRD patterns of the smelting products are presented in Fig. $7 \mathrm{a}$ and $\mathrm{b}$. It can be observed that three products were obtained, visibly separated as distinct layers by settling, i.e., slag, ferrous matte, and crude lead bullion. The chemical compositions of the different products obtained and the element distribution behavior is presented in Fig. 7c and Table S-II (Supplementary Material).
The above results validate the reductive sulfurfixing technique as being experimentally feasible for recycling LAB paste. More than $96.2 \%$ of the lead and $98.9 \%$ of the sulfur $(89.6 \%$ in the matte and $9.3 \%$ in the slag) in the raw materials were extracted and fixed within $1.5 \mathrm{~h}$ at $1200^{\circ} \mathrm{C}$. Crude lead bullion with purity of 98.6 wt.\% $\mathrm{Pb}$ was obtained. The lead content in the matte and slag were $2.6 \mathrm{wt} . \%$ and $0.5 \mathrm{wt} . \%$, respectively. The major constituent in the matte was $\mathrm{FeS}$. Some $\mathrm{CaS}, \mathrm{Fe}_{3} \mathrm{O}_{4}$, and unreacted $\mathrm{PbS}$ as well as entrained gangue materials such as $\mathrm{Ca}_{3} \mathrm{Al}_{2}\left(\mathrm{SiO}_{4}\right)_{3}, \mathrm{FeSiO}_{3}, \mathrm{Ca}_{2} \mathrm{Al}(\mathrm{Al}-$ Si) $\mathrm{O}_{7}$, and $\mathrm{CaSiO}_{3}$ were also detected. The solidified slag comprised $\mathrm{Ca}_{2}\left(\mathrm{Al}(\mathrm{AlSi}) \mathrm{O}_{7}, \mathrm{Fe}_{2} \mathrm{SiO}_{4}, \mathrm{CaFe}_{4} \mathrm{O}_{7}\right.$, $\mathrm{NaAlSiO}_{4}, \mathrm{Na}_{2} \mathrm{Si}_{2} \mathrm{O}_{5}, \mathrm{CaSiO}_{3}, \mathrm{Fe}_{3} \mathrm{O}_{4}, \mathrm{Ca}_{2} \mathrm{Al}_{2}\left(\mathrm{SiO}_{4}\right)_{3}$, and some entrained $\mathrm{FeS}$.

The matte and slag that were obtained were further characterized by SEM-EDS analysis. The results are shown in Fig. 8. Figure 8a-d shows that, in the matte, mackinawite mineral $\mathrm{FeS}$ was bonded to magnetite $\mathrm{Fe}_{3} \mathrm{O}_{4}$. Sodium iron sulfide $\mathrm{NaFeS}_{2}$ and galena $\mathrm{PbS}$ filled the gaps between the 

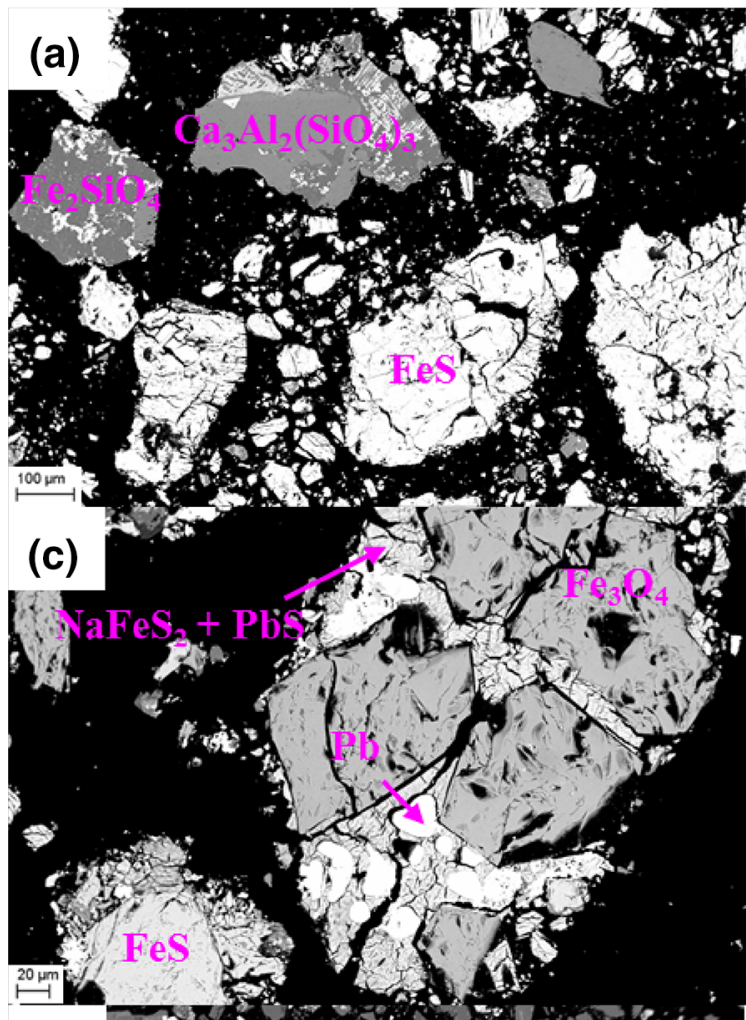

(e)
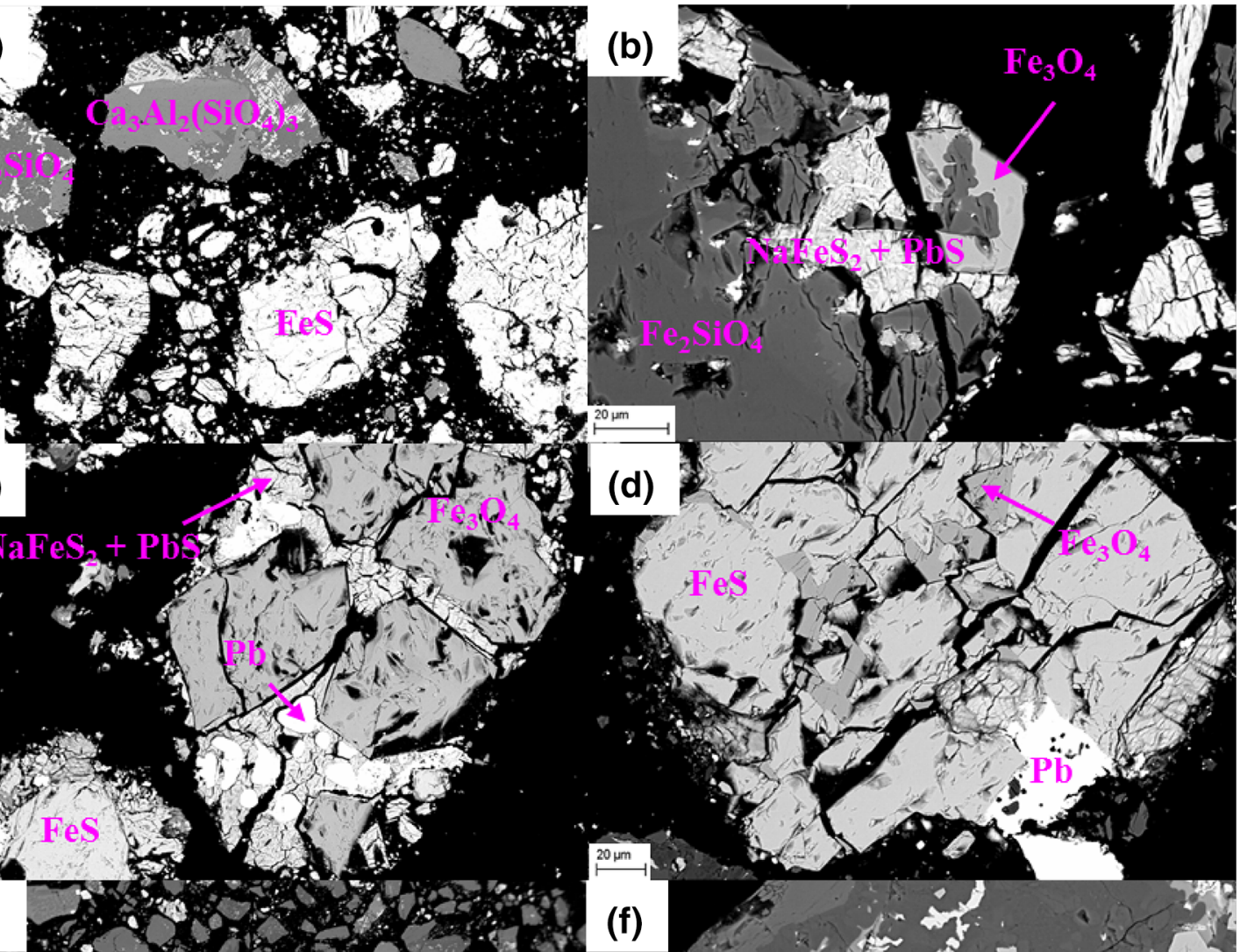

(d)
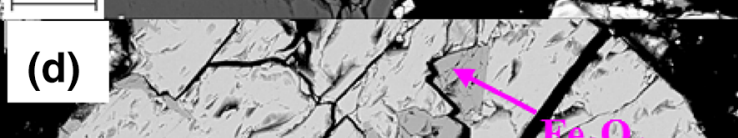
i.

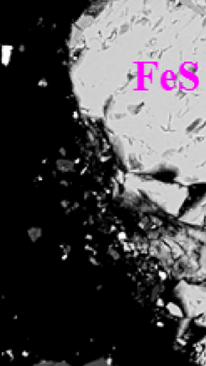
$\rightarrow$,

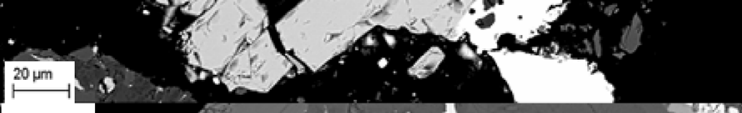

(f)
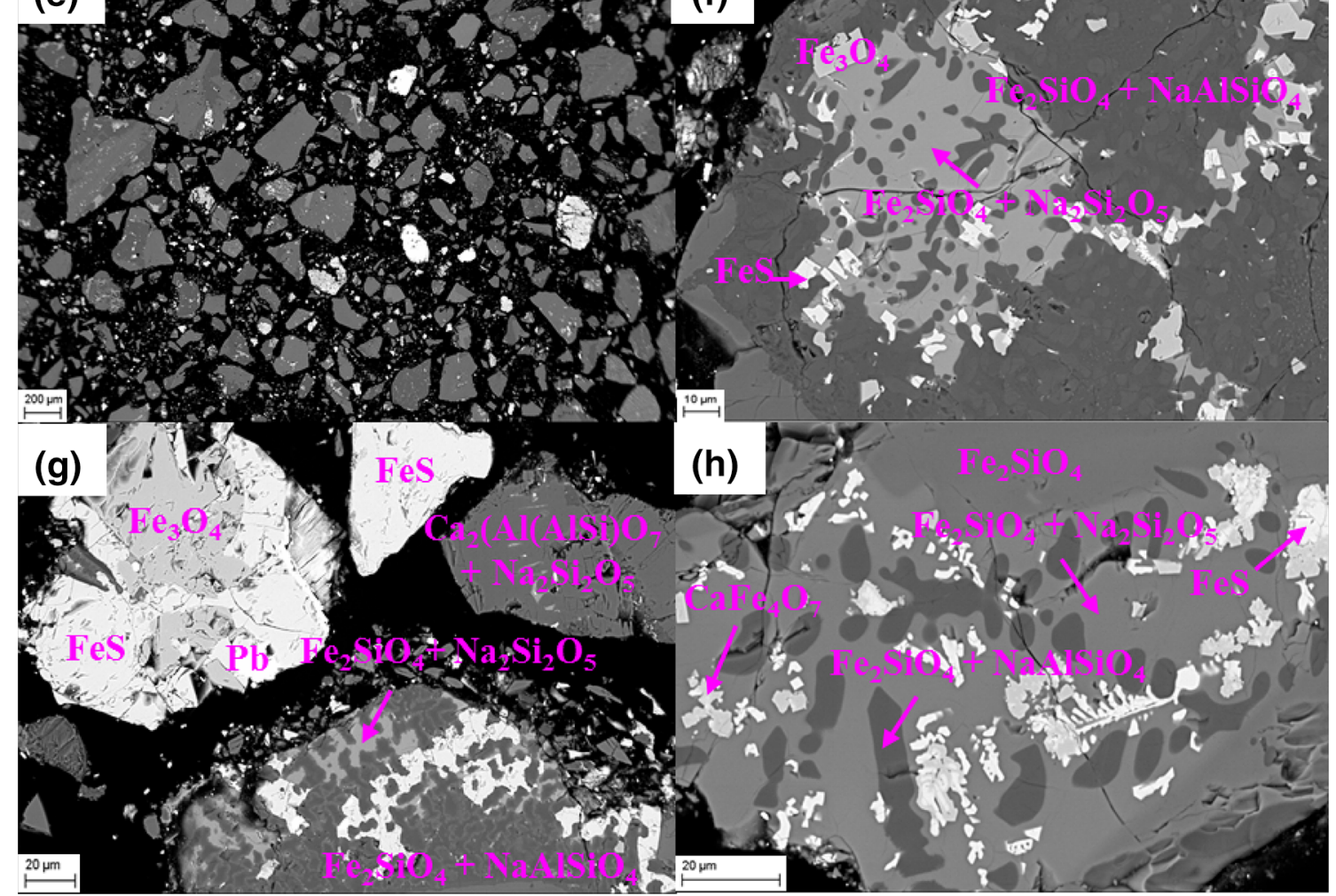

Fig. 8. SEM micrographs of the experimental bench-scale pilot products; (a)-(d) matte; (e)-(h) slag. 
magnetite minerals. Metallic $\mathrm{Pb}$ was detected, embedded in the $\mathrm{FeS}$ and $\mathrm{NaFeS}_{2}$ minerals. In the slag, as shown in Fig. 8e-h, sodium aluminosilicate $\left(\mathrm{NaAlSiO}_{4}\right)$ and sodium disilicate $\left(\mathrm{Na}_{2} \mathrm{Si}_{2} \mathrm{O}_{5}\right)$ dissolved in fayalite $\mathrm{Fe}_{2} \mathrm{SiO}_{4}$ and gehlenite $\mathrm{Ca}_{2}(\mathrm{Al}(\mathrm{Al}-$ $\mathrm{Si} \mathrm{O}_{7}$. Mackinawite $\mathrm{FeS}$ was entrained in the magnetite $\mathrm{Fe}_{3} \mathrm{O}_{4}$ and calcium iron oxide $\mathrm{CaFe}_{4} \mathrm{O}_{7}$ minerals, and magnetite had separated out from the fayalite matrix. These results agree well with the thermodynamic phase diagram calculations above.

\section{CONCLUSION}

Effective lead extraction from LAB paste by a reductive sulfur-fixing recycling technique was shown to be feasible, thermodynamically and experimentally. The reaction mechanism investigations revealed that the presence of $\mathrm{Na}_{2} \mathrm{CO}_{3}$ helped to transform $\mathrm{SO}_{3}$ from $\mathrm{PbSO}_{4}$ to $\mathrm{Na}_{2} \mathrm{SO}_{4}$ at low temperatures and in weakly reductive atmospheres. This ensures the conservation of sulfur in the smelting system without emitting gaseous $\mathrm{SO}_{2}$ to the atmosphere. Once the atmosphere was sufficiently reductive, $\mathrm{PbSO}_{4}$ was reduced to $\mathrm{PbS}$. Thus, the sulfurfixing agent $\mathrm{Fe}_{3} \mathrm{O}_{4}$ reacted with $\mathrm{PbS}$ to transfer sulfur to iron matte. Finally, metallic lead was extracted from $\mathrm{PbO}$, and sulfur was fixed as $\mathrm{FeS}$ and $\mathrm{NaFeS}_{2}$. The lead extraction and sulfur-fixing reactions followed the shrinking unreacted-core model. Furthermore, bench-scale experiments using lead paste as raw material validated the fact that three recycling products were obtained: slag, matte, and crude lead bullion. More than $96.2 \%$ of the lead and $98.9 \%$ of the sulfur in the raw materials were extracted and fixed. The purity of the crude lead bullion was $98.6 \% \mathrm{~Pb}$. The lead content in the matte and slag was decreased to $2.6 \%$ and $0.5 \%$ in the onestep treatment, respectively. This new process can be used for cotreating various iron-containing solid wastes and residues, and for comprehensive recycling of a variety of valuable metals compatible with iron matte and metallic lead.

\section{ACKNOWLEDGEMENTS}

Open access funding provided by Aalto University. This work is supported by the Specialized Research Project of Guangdong Provincial Applied Science and Technology, China (Grant No. 2016B020242001), Hunan Provincial Science Fund for Distinguished Young Scholars, China (Grant No. 2018JJ1044), National Natural Science Foundation of China (Grant Nos. 51234009 and 51604105), CMEco by Business Finland (Grant No. 2116781), National Natural Science Foundation for Less Developed Regions of China (Grant No. 51664013), Program for Young Talents of Science and Technology in Universities of the Inner Mongolia, China (Grant No. NJYT-17-B35), and Bayannur Science and Technology Project from Bayannur Bureau of Science and Technology for Wang Yuejun, China (Grant No. K201509).

\section{OPEN ACCESS}

This article is distributed under the terms of the Creative Commons Attribution 4.0 International License (http://creativecommons.org/licenses/by/4.0/), which permits unrestricted use, distribution, and reproduction in any medium, provided you give appropriate credit to the original author(s) and the source, provide a link to the Creative Commons license, and indicate if changes were made.

\section{ELECTRONIC SUPPLEMENTARY MATERIAL}

The online version of this article (https://doi.org/ 10.1007/s11837-019-03529-1) contains supplementary material, which is available to authorized users.

\section{REFERENCES}

1. Q. Zhang, Int. J. Electrochem. Sci. 8, 6457 (2013).

2. X. Tian, Y. Wu, Y. Gong, and T. Zuo, Waste Manag. Res. 33, 986 (2015).

3. Z. Sun, H. Cao, X. Zhang, X. Lin, W. Zheng, G. Cao, Y. Sun, and Y. Zhang, Waste Manag. 64, 190 (2017).

4. T.W. Ellis and A.H. Mirza, J. Power Sources 195, 4525 (2010).

5. D. Lin and K. Qiu, Waste Manag. 31, 1547 (2011).

6. R.A. Huggins, Lead-Acid Batteries (US: Springer, 2016).

7. D. Andrews, A. Raychaudhuri, and C. Frias, J. Power Sources 88, 124 (2000).

8. J. Weijma, K. de Hoop, W. Bosma, and H. Dijkman, Biotechnol. Prog. 18, 770 (2002).

9. A. Schröder-Wolthoorn, S. Kuitert, H. Dijkman, and J.L. Huisman, Hydrometallurgy 94, 105 (2008).

10. M.A. Kreusch, M.J.J.S. Ponte, H.A. Ponte, N.M.S. Kaminari, C.E.B. Marino, and V. Mymrin, Resour. Conserv. Recycl. 52, 368 (2007).

11. X. Zhang, L. Li, E. Fan, Q. Xue, Y. Bian, F. Wu, and R. Chen, Chem. Soc. Rev. 47, 7239 (2018).

12. Y. Li, S. Yang, W. Lin, P. Taskinen, J. He, Y. Wang, J. Shi, Y. Chen, C. Tang, and A. Jokilaakso, Minerals 9, 119 (2019)

13. R. Prengaman and A. Mirza, Lead-Acid Batteries for Future Automobiles (Amsterdam: Elsevier, 2017), p. 575.

14. E. Kim, J. Roosen, L. Horckmans, J. Spooren, K. Broos, K Binnemans, K.C. Vrancken, and M. Quaghebeur, Hydrometallurgy 169, 589 (2017).

15. A. Singh and P. Karandikar, Microsyst. Technol. 23, 2263 (2017).

16. T.J. Van der Kuijp, L. Huang, and C.R. Cherry, Environ. Health 12, 61 (2013).

17. X. Tian, Y. Wu, P. Hou, S. Liang, S. Qu, M. Xu, and T. Zuo, J. Clean. Prod. 144, 142 (2017).

18. A.D. Ballantyne, J.P. Hallett, D.J. Riley, N. Shah, D.J. Payne, and R. Soc, Open Sci. 5, 171368 (2018).

19. Y. Li, S. Yang, P. Taskinen, J. He, F. Liao, R. Zhu, Y. Chen, C. Tang, Y. Wang, and A. Jokilaakso, J. Clean. Prod. 217, 162 (2019).

20. M. L. Jaeck, in Primary and Secondary Lead Processing: Proceedings of the International Symposium on Primary and Secondary Lead Processing, Halifax, Nova Scotia, Canada, August 20-24, Elsevier, Amsterdam (2013), p. 113.

21. Y. Hu, C. Tang, M. Tang, Y. Chen, J. Yang, S. Yang, and J. He, China Nonferr. Metall. 43, 75 (2014).

22. L. Ye, C. Tang, Y. Chen, S. Yang, J. Yang, and W. Zhang, J. Clean. Prod. 93, 134 (2015).

23. Y. Li, C. Tang, Y. Chen, S. Yang, L. Guo, J. He, and M. Tang, in 8th International Symposium on High-Tempera- 
ture Metallurgical Processing, TMS, San Diego, CA, US, March 23-26 (Springer, Cham, 2017), p. 767.

24. B. Toby, J. Appl. Crystallogr. 38, 1040 (2005).

25. A. Roine, HSC Chemistry for Windows, vers. 9.2.6 (Outotec Research, Pori, Finland, 2019). www.hsc-chemistry.com.

26. MTDATA ver. 8.2. (NPL, Teddington, 2015). https://mtdat a.com.au/.

27. J. Gisby, P. Taskinen, J. Pihlasalo, Z. Li, M. Tyrer, J. Pearce, K. Avarmaa, P. Björklund, H. Davies, M. Korpi, S.
Martin, L. Pesonen, and J. Robinson, Metall. Mater. Trans. $B$ 48B, 91 (2017).

Publisher's Note Springer Nature remains neutral with regard to jurisdictional claims in published maps and institutional affiliations. 